\title{
Investigation on the effect of fiber reinforcement style on shear properties of polypropylene composites
}

\section{Elyaf takviye biçiminin polipropilen kompozitlerin kayma özelliklerine etkisinin araştırılması}

\author{
Abdullah Onur OZDEMIR+ ${ }^{+}$(iD), Regaip MENKUC ${ }^{2}$ (D) Cetin KARATAS $^{3}$ (i) \\ 1,2Department of Automotive Engineering, Technology Faculty, Gazi University, Ankara, Turkey. \\ onurozdemir@gazi.edu.tr, rmenkuc@gazi.edu.tr \\ ${ }^{3}$ Department of Manufacturing Engineering, Technology Faculty, Gazi University, Ankara, Turkey. \\ cetink@gazi.edu.tr
}

\begin{abstract}
One of the most important failures that occur during the forming of laminated composite materials is shear failure. Interlaminar shear strength is examined to determine this mechanism of damage. In this study, bending test via the short beam method was applied to thermoplastic composite laminates with two different compositions. It was aimed to analysis on the effects of the glass fiber architecture types on shear properties of the thermoplastic composite laminates. Both types of composite laminates have $3 \mathrm{~mm}$ thickness, the matrix element is Polypropylene and the reinforcing element is glass fiber. The first material has a fiber ratio of $60 \%$ and a continuous fiber stacked at $0 / 90$ in its structure. The fiber content of the second material is 38\% and it contains both chopped and woven continuous fiber. The interlayer shear properties of two kinds of composite laminates containing reinforcement elements in different types were compared. In addition, failure situations were examined by performing macro imaging. The shear strength of the composite laminate containing chopped fiber was higher than the composite material with high continuous fiber weight ratio.
\end{abstract}

Keywords: Shearing failure, Shear strength, Short beam test, Thermoplastic composite laminate.

\section{Introduction}

When it has been compared with traditional materials, polymer composites have been used in automotive industry as well as other fields because of their high specific strength (strength/density) [1],[2]. While thermoset composites have been used in aerospace and defense industries in consequence of their sufficient thermal resistance and rigidity, thermoplastic composite laminates have come into prominence in the automotive industry due to their availability of recycling and mass production [3],[4]. Thermoplastic polymers don't need a curing process unlike thermosets and they are formed easily because they exhibit a ductile behavior when they are heated [5],[6]. Glass and carbon fiber have been used frequently as a reinforcement agent in polymer composites by virtue of their outstanding qualifications [7]. The polymer composites are reinforced with carbon fiber, when high performance is required. However, carbon fiber having a high production cost has a disadvantage in industrial applications use which has an high manufacturing volume and requires low cost. Hence, as a

\section{Öz}

Kompozit levha malzemelerin șekillendirilmesi strasinda meydana gelen en önemli hasarlardan birisi de kayma hasarıdır. Bu hasar mekanizmasının belirlenmesi için tabakalar arası kayma direnci incelenmektedir. $\mathrm{Bu}$ çalıșmada, iki farklı kompozisyona sahip termoplastik kompozit levhalara kısa kiriş metoduyla eğme testi uygulanmıștır. Cam elyaf mimarisinin termoplastik kompozit levhaların kayma özellikleri üzerindeki etkilerinin incelenmesi amaçlanmıștır. Her iki tür kompozit levha da $3 \mathrm{~mm}$ kalınlıkta olup, matriks elemanı Polipropilen ve takviye elemanı cam elyaftır. Birinci malzemenin yapısında 0/90 dizilmiș ve $\% 60$ oranda sürekli elyaf bulunmaktadır. Íkinci malzeme ise \% 38 oranda hem kırpılmıs hem de dokunmuş sürekli elyaf içermektedir. Farklı biçimlerde takviye eleman içeren iki tür kompozit levhanın tabakalar arası kayma özellikleri karşıllaştırılmıştır. Ayrıca, makro görüntüleme yapılarak hasar durumları incelenmiștir. Hibrit elyaf içeren kompozit levhanın kayma dayanımı, kütlece sürekli elyaf oranı fazla olan kompozit malzemeye göre daha yüksek çıkmıștır.

Anahtar kelimeler: Kayma hasarı, Kayma dayanımı, Kısa kiriş metodu, Termoplastik kompozit levha.

reinforcement the glass fiber which has a low strength compared to carbon fiber is at the forefront in automotive industry because of its cost-effectiveness [8]. Laminate thermoplastic composites containing both chopped and continuous fiber have a potential in recent years thanks to their availability of being formed in a thermoform mold which is a fast and cheaper manufacturing technique [9]. Preconsolidated multilayer composite structures simplify manufacturing processes and increase the performance of the final components [10]. Composite laminates have some advantages over conventional hand lay-up method for fabricating composites, such as obtaining the final product in short cycle times, ease of storage and transport [11]. However, there are some difficulties in forming laminated composites in complex geometries. Shearing and delamination are the primary challenges [12].

Forming failures (matrix crack, fibre breaking, interlaminar or intra-laminar delamination) damaging the structural integrity during the forming process of polymer composites has a dramatic effect in mechanic behaviors of the material. A

${ }^{*}$ Corresponding author/Yazışılan Yazar 
number of investigations have been carried out in order to determine these kinds of deformation and compare the characteristic qualifications of the composite materials [13]. Mechanical properties of fiber and matrix, interface properties and especially fiber configuration among the material variables have important roles in determining delamination resistance [14],[15]. Delamination resistance in composite laminates has been expressed as interlaminar shear strength. Different kinds of tests have been used for interlaminar shear strength such as Iopescu, short beam and double-notch shear tests. Researchers have generally preferred the short beam shear test because of its ease of use [16],[17].

Yan et al. have prepared prepreg composites by reinforcing continuous glass fiber to the polyethylene terephthalate (PET) oligomer with solid state polycondensation method and investigated the effects of condensation reaction time on mechanical properties of the material. Interfacial adhesion has been increased with wettability by controlling the condensation time and shear, impact and flexure strengths have been improved [18]. Wang et al. have examined the interlaminar shear behaviors of glass fiber reinforced polypropylene composites manufactured by molding at different cooling rates. The highest shear strength has occurred in composite laminates containing long-chopped fiber when it is compared to composites with woven and unidirectional fiber layers [19]. Fan et al. have characterized the composites prepared by injecting epoxy suspensions containing multi wall carbon nanotubes into the glass fiber reinforced prepreg and confirmed 33\% increase in interlaminar shear strength [20]. Kumar et al. have compared the mechanical properties of carbon/glass fiber reinforced thermoset/thermoplastic composites and determined that interlaminar shear strength of laminates containing polypropylene matrix is lower than epoxy matrix laminates [21]. Visweswaraiah et al. have examined the shear behaviors of the materials which are hybrid reinforced and have four different fiber orientations. The interlaminar shear strengths have been determined as ROS (randomly oriented strands), TRT (unidirectional-choppedunidirectional), RT (chopped-unidirectional), and RTR (chopped-unidirectional-chopped). It has been stated that ROS has $25 \%$ more shear strength than RTR [22]. Huang et al. have investigated the effect of the thickness of layers constituting composite laminates on shear strength. Thin prepregs have caused a decrease in anisotropy and the shear strength has increased with the material looking alike homogeneous mesostructure [23]. Aisyah et al. have searched the effects of weaving pattern being a hybrid reinforcement agent on mechanical properties of composite laminates. It has been determined that the fabric count of $5 \times 5$ is more convenient than the $6 \times 6$ count and satin fabric in terms of tensile, impact and shear strengths [24]. Bilisik et al. have examined the effect of stitching the woven fiber plies together on the shear strength. The shear strength has increased in the composite materials containing fiber stitched with aramid fiber in comparison with the seamless fiber and has shown a significant increase in the composite stitched with carbon fiber [25]. Awais et al. evaluated the damage behaviors of the woven/commingled/knitted natural fabrics reinforced thermoplastic composite sheets by means of the short-beam shear and the drop-weight impact strengths. The knitted composites were determined to showed higher shear strength compared to the others thanks to the interlocking of the fibers and the effect of the fiber architecture was revealed on the composite sheet properties [26].

According to the present literature, it has been explained that shear is the main problem for evaluating strength and failure tolerance of the composite laminates. Because they have good balance between costs and performance, polypropylene as matrix and glass fibers as reinforcement most used in thermoplastic based composites. However, the properties of the composite material are related to fiber architecture and polymer compatibility [27]. In this study, bending experiments have been carried out by applying short beam test to polypropylene composite materials with reinforced $0 / 90$ aligned or chopped/woven glass fiber having different ratios. The shear strength and failure behaviors have been investigated according to fiber configuration.

\section{Material and methodology}

In this work, thermoplastic laminates which has two different reinforcement types have been used. Their thicknesses are 3 $\mathrm{mm}$, their matrix elements are polypropylene and their reinforcement elements are glass fiber. First material (N1) has $60 \%$ continuous fiber by weight which has $[0 / 90]_{3}$ aligned. Second material (N2) contains 38\% fiber both chopped and woven. Structural forms of the laminates have been shown in Figure 1 schematically. The fiber in the structure of N2 is not uniform. It contains $80 \%$ yarn density continuous fiber in $0^{\circ}$ and $20 \%$ in $90^{\circ}$. The longitudinal $\left(0^{\circ}\right)$ and transversely $\left(90^{\circ}\right)$ tensile and flexural strengths of the laminates have been given in Table 1. E-glass fiber in material $\mathrm{N} 1$ has an area weight of $400 \mathrm{~g} / \mathrm{m}^{2}$ and material $\mathrm{N} 2$ contains $13 \%$ woven with an area weight of $430 \mathrm{~g} / \mathrm{m}^{2}$ and $25 \%$ chopped E-glass fiber. Only a few manufacturers produce thermoplastic composite laminates that can be used commercially, and they release composites with different structures from each other as laminates. Furthermore, the products of two companies manufacturing with the matched-die consolidation technique discussed in this study. In addition, the areal weights of the continuous fiber ply and the tensile strengths of both materials are very close to each other. When the literature was examined, it was seen that the length and thickness of the laminate played a dominant role in the short beam and three-point bending tests [16],[17]. Therefore, in this study, N1 and N2 composite laminates of the same thickness were examined.

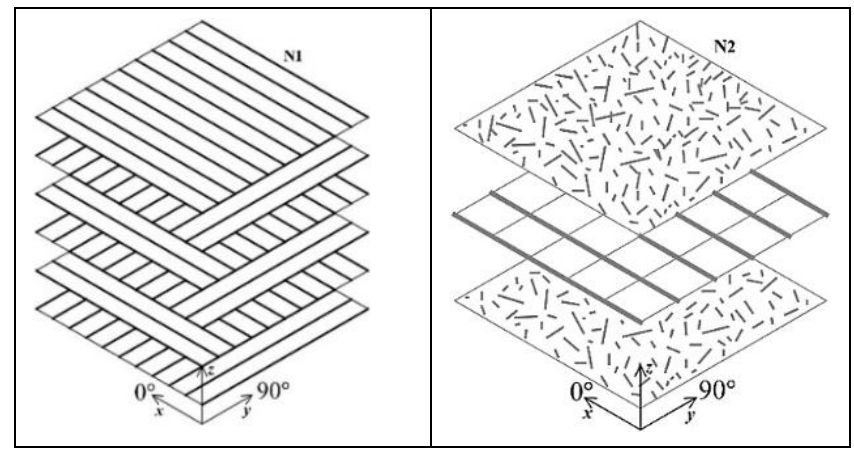

Figure 1. Reinforcement element structures.

Table 1.Tensile and flexural strengths of specimens.

\begin{tabular}{ccccc}
\hline & \multicolumn{2}{c}{$\mathrm{N} 1$} & \multicolumn{2}{c}{$\mathrm{N} 2$} \\
& $90^{\circ}$ & $0^{\circ}$ & $90^{\circ}$ & $0^{\circ}$ \\
\cline { 2 - 5 } Tensile strength $(\mathrm{MPa})$ & 220 & 220 & 85 & 185 \\
Flexural strength $(\mathrm{MPa})$ & 105 & 105 & 110 & 175 \\
\hline
\end{tabular}


The bending tests carried out by using short beam method have been done with Instron-3369 universal test machine. Taking as reference to ISO 14130 Standard; the suitable fixture has been attached to the machine and the specimen have been placed on supports as it is shown in Figure 2 [28]. The radius of the loading element $\left(R_{1}\right)$, the radius of supports $\left(r_{2}\right)$ and the span distance $(L)$ are $5 \mathrm{~mm}, 2 \mathrm{~mm}$ and $5 \mathrm{~mm}$ respectively.

The test speed has been chosen as $1 \mathrm{~mm} / \mathrm{min}$. The specimens have been cut via water jet with the dimensions of $50 \times 25 \mathrm{~mm}^{2}$. It is known that the highest shear level occurs on the midplane of the loaded beam according to the beam theory in the threepoint bending processs, and is related to the specimen width and thickness [29].

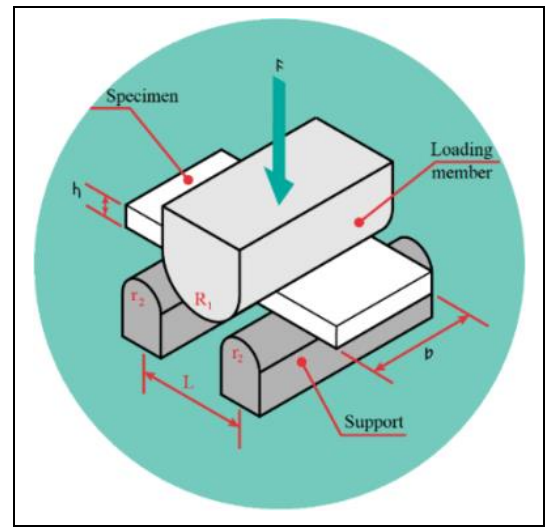

Figure 2. Experimental procedure.

The interlaminar shear strength $(\tau)$ has been calculated as in equation 1 . In this equation $F, b$ and $h$ have been given as the force applied from center $(N)$, the specimen width $(\mathrm{mm})$ and the specimen thickness $(\mathrm{mm})$ respectively [30].

$$
\tau=\frac{3}{4} \times \frac{F}{b \times h}
$$

\section{Results and evaluation}

In this section, the results of bending tests carried out with short beam method at room temperature have been explained along with graphics. The specimens prepared from composite laminates in two different structures in XZ and yz planes have been positioned on two supports and bending load has been applied at the midpoint. Obtained force and displacement have been recorded and then their shear strength has been calculated. Besides, the damage cases of the specimens have been evaluated after the experiment.

The displacement and the corresponding force values recorded during the experiment have been shown in Figure 3 for N1. Maximum forces for N1-Xz and N1-yz have been obtained as $988 N$ and $1087 N$ respectively. The values in $\mathrm{N} 1$ have been very close to each other in both $\mathrm{xz}$ and $\mathrm{yz}$ planes because they contain equal fiber in two perpendicular directions. The composite laminate designed with unidirectional fiber lined up $0 / 90$ has showed a decrease like shoulder after the maximum force in $\mathrm{N} 1$.

The force change curves for N2 depending on the displcement have been shown in Figure 4 . There has been a significant difference in $\mathrm{N} 2$ since the fiber density of $\mathrm{XZ}$ plane is lower than density in yz plane. While the maximum force for N2-XZ is 1241 $N$, it has reached $1834 N$ for N2-yz. Rising force with the increasing displacement has started to decrease after a certain point. In composite laminate $\mathrm{N} 2$, which involves denser continuous fiber in $0^{\circ}$ direction than in $90^{\circ}$ direction, the applied force in the plane perpendicular to the weak fiber direction has suddenly decreased and the applied force perpendicular to the plane where the continuous fiber is four times has almost remained stable after a certain deflection. Zhu et al. have determined in their study that nano-sized fiber particles has a stiffening effect and improve the plane properties such as shear/bending [31]. Concordantly, it has been seen in our study that chopped fiber enhances interface features by strengthen the matrix directly.

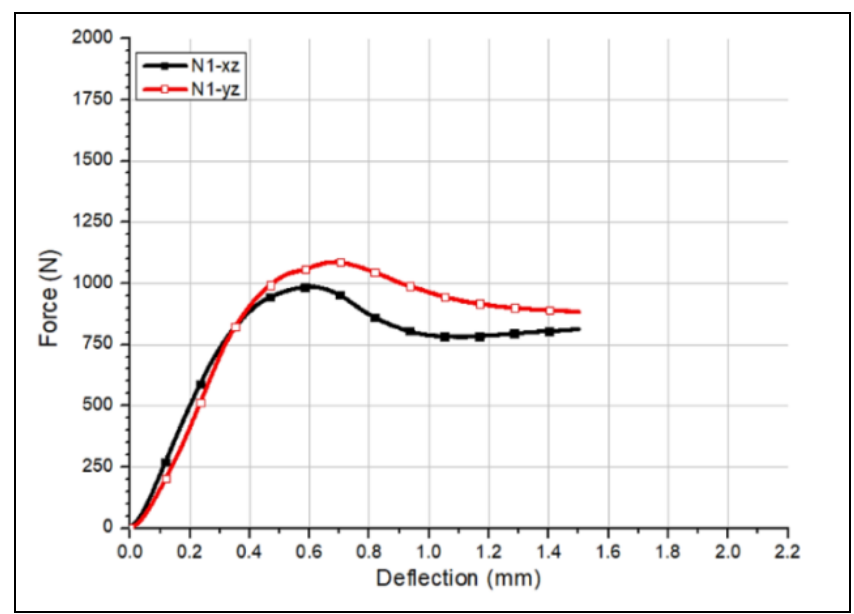

Figure 3. Force change versus displacement of N1.

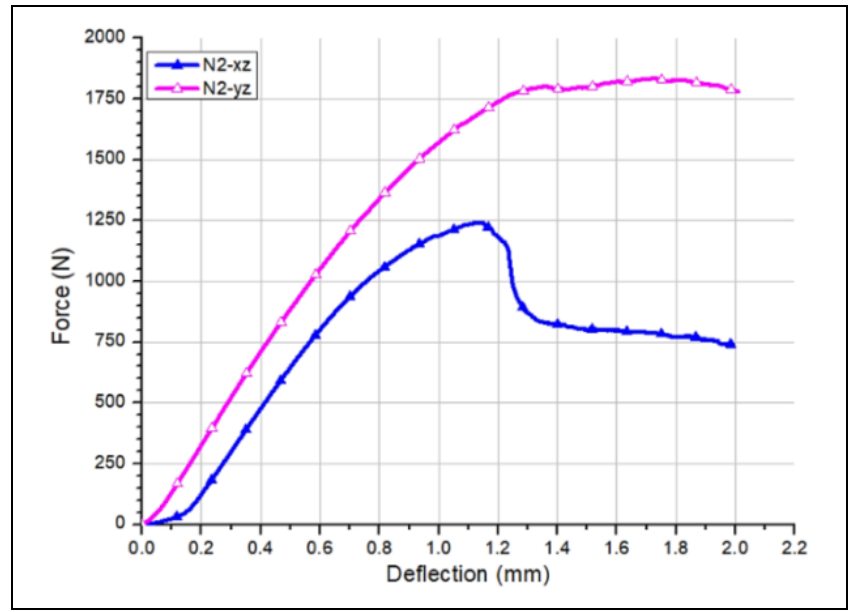

Figure 4. Force change versus displacement of N2.

$\mathrm{N} 1$ has shown less force increase than N2 in both directions. Wang et al. have reported in their study that chopped fiber increases the shear strength [19]. Maximum force values and their displacement levels according to the results of shear experiment have been given in Table 2 .

Table 2. Force values and deflection amounts.

\begin{tabular}{ccccc}
\hline & \multicolumn{2}{c}{$\mathrm{N} 1$} & \multicolumn{2}{c}{$\mathrm{N} 2$} \\
& $\mathrm{xz}$ & $\mathrm{yz}$ & $\mathrm{xz}$ & $\mathrm{yz}$ \\
\cline { 2 - 5 } Force $(k N)$ & 988 & 1087 & 1241 & 1834 \\
Deflection $(\mathrm{mm})$ & 0.60 & 0.68 & 1.14 & 1.72 \\
\hline
\end{tabular}

Applied bending force has caused shear stress in composite laminates. The resistances of the specimens put up shear, which calculated using equation (1) have shown comparatively in 
Figure 5. The shear strengths of N1-xz and N1-yz have been determined as $9.9 \mathrm{MPa}$ and $10.8 \mathrm{MPa}$ respectively. The shear strengths of $\mathrm{N} 2-\mathrm{xz}$ and $\mathrm{N} 2-\mathrm{yz}$ have been determined as 12.4 MPa and 18.4 MPa respectively. There has been $48 \%$ more shear strength in N2-Xz than yz plane. The fact that the fiber was proportionally woven at unequal densities caused this difference. A clear difference has been seen between the shear strengths of $\mathrm{N} 1$ and N2. Although the fiber ratio of N1 is high, N2 containing chopped fiber has more toughness. Seyhan et al. have obtained similar results in their studies and explained that adding fiber nanotubes into the matrix has improved the mechanical properties of composite materials more effectively than macro-scale fillers [32].

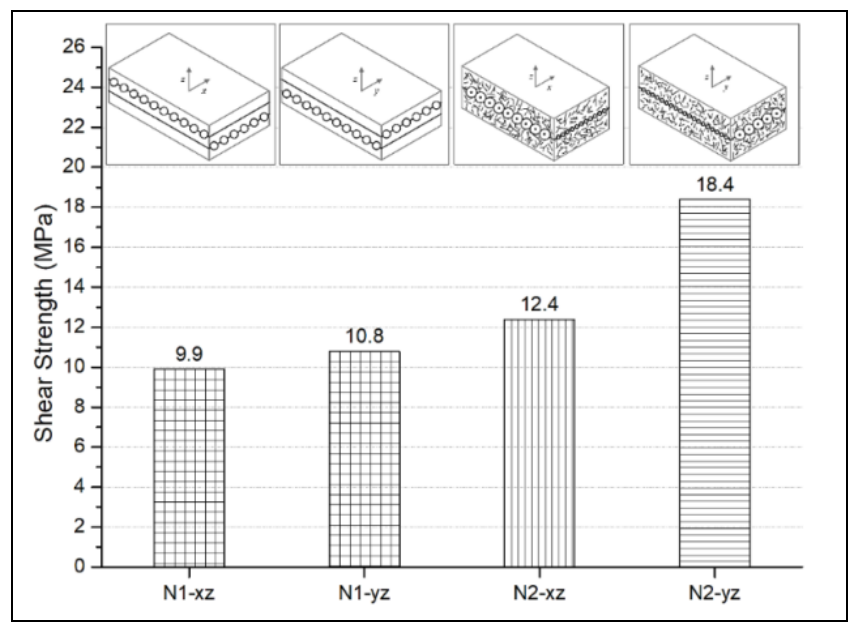

Figure 5. Comparison of maximum shear strengths.

Experiments were repeated three times and similar results were obtained in triplicate. Standard deviations related to the averaged shear strength values after repetitive experiments have been presented in Table 3. It was observed that the shear strength results coincided with the three-point bending results given in Table 1. In the three-point bending test, the span range and specimen length are longer, and accordingly, the specimen is subjected to tensile and compressive stresses. It is the length/thickness ratio that is effective in both bending tests [33]. Therefore, the shear and flexural strengths resulted in a similar trend. About ten-times the difference was determined between the maximum strengths. By highlighting the shear defect that occurs during flexure, the shear strength may be determined more accurately. In this context, the distance between the beams is kept very short to eliminate other defects. This is the main difference from the three-point bending test. However, the laminate thickness used in this study prevented further shortening of the span interval. The shortest possible interval was used in this study.

Table 3. Shear strength values and standard deviations.

\begin{tabular}{ccccc}
\hline & \multicolumn{3}{c}{$\mathrm{N} 1$} & \multicolumn{2}{c}{$\mathrm{N} 2$} \\
\cline { 2 - 5 } & $\mathrm{xz}$ & $\mathrm{yz}$ & $\mathrm{xz}$ & $\mathrm{yz}$ \\
\cline { 2 - 5 } & 9.9 & 10.8 & 12.4 & 18.4 \\
Shear strength $(\mathrm{MPa})$ & 0.4 & 1.7 & 2.2 & 1.6 \\
Standard deviations $(\mathrm{MPa})$ & 0.4 \\
\hline
\end{tabular}

The specimens have been exposed to inside compressive stress and outside tensile stress in axis of flexure during the experiments. The shear failures of $\mathrm{N} 1$ have been shown in Figure 6. Local compressive deformations have occurred in every specimen. In addition to this, the delamination has not occur prominently. Interlaminar shear has occurred albe partially. A quite stable state has been observed against the shear mechanism in $\mathrm{N} 1$. There has been no difference depending on $\mathrm{XZ}$ and $\mathrm{yz}$ planes because $\mathrm{N} 1$ has unidirectional fiber layers in $0^{\circ}$ and $90^{\circ}$ aligned. Permanent intrusions have been taken place in the specimen center. Fiber bundles have been exposed to inelastic flexure along the axis of shear thanks to bonding strong matrix. Kinking failure has been occurred on the line where supports touch on specimens tangentially.

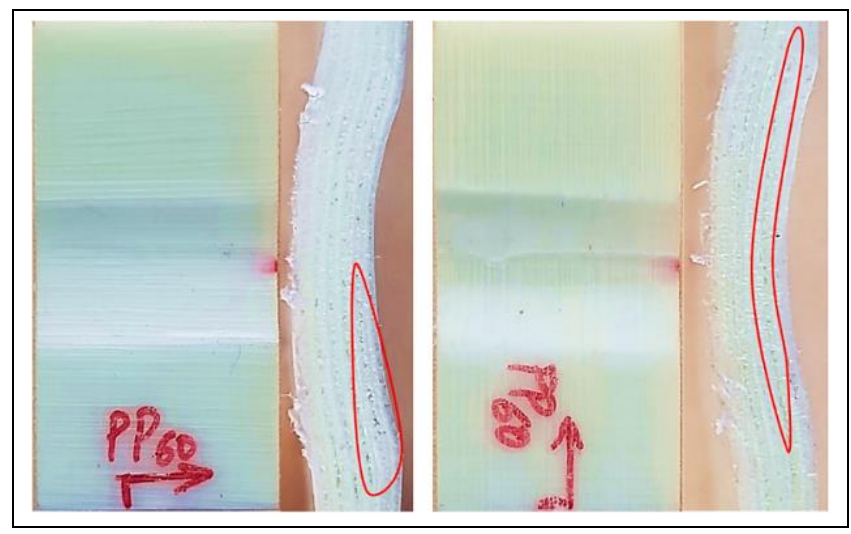

Figure 6. Photomacrography of N1.

The failure cases of $\mathrm{N} 2$ after the bending experiment have been shown in Figure 7. Despite it is not balanced, the fact that it contains woven fiber made N2 more reliable against shear failure. Chopped fiber has increased the shear strength by improving the interface bonding however, it has caused brittle in the structure. As it can be understand from high transverse shear strength, the bending rate and the shear stress are directly proportional. A gap has been occurred due to the lateral matrix cracking on the outside. A pronounced defects has not been observed between the matrix and the continuous fiber; even so, in the transverse direction bending, a little matrix crazing started under the weaving layer. Also, there observed fiber breaking in the outer side. Chopped fiber additive improved the interaction between interfaces and contributed to the shear strength. The woven fabric has wavy regions due to its weave structure and these regions prevent the increase in mechanical properties [34]. N2 composite reinforced with chopped fibers for this reason, also it increased its shear strength by improving the bonding in layers.

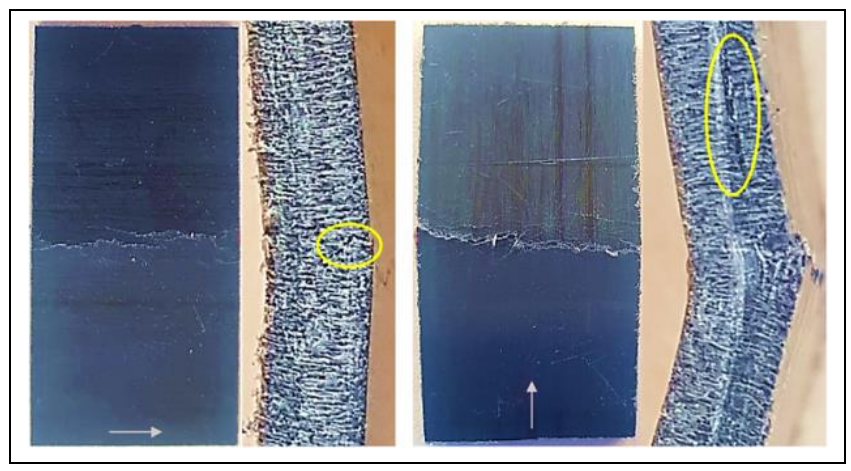

Figure 7. Photomacrography of N2.

\section{Conclusion}

In the present work, the effect of fiber configuration in thermoplastic composite laminates on shear strength and failure was investigated. Longitudinal and transverse bending 
test was applied to glass fiber reinforced two different composite materials having polypropylene matrix with a laminate thickness of $3 \mathrm{~mm}$ using the short beam method.

- While the maximum force has increased, the deflection rate at which this force occurs has also raised,

- Chopped glass fiber has improved the shear strength however, it has also increased the deformation,

- It was determined that the shear strength of composite containing woven fabric is high on the plane where continuous fiber yarn density is more,

- It was determined that the composite laminate having 0/90 aligned has the same shear strength longitudinally and transversely, and the buckling deformation was permanent,

- Using the chopped and woven continuous fiber together has affected the shear strength positively.

\section{Acknowledge}

We thank to Quadrant Plastic Composites A.G. and Durfoam Insulation \& Packaging Co. for their help in procuring the composite laminate materials used in this study and Gazi University Rectorate Scientific Research Project Department supporting this study within Project No: 07/2018-15.

\section{Author contribution statements}

In the scope of this study, Abdullah Onur OZDEMIR, in the formation of the idea, literature review, supplying the materials used, performing experiments, assessment of obtained results, writing, spelling; Regaip MENKUC in the design, performing experiments, collecting data; Cetin KARATAS in the obtaining resources, check the article in terms of content, critical review were contributed.

\section{Ethics committee approval and conflict of interest statement}

There is no need to obtain permission from the ethics committee for the article prepared.

There is no conflict of interest with any person/institution in the article prepared.

\section{References}

[1] Agarwal K, Kuchipudi SK, Girard B, Houser M. "Mechanical properties of fiber reinforced polymer composites: A comparative study of conventional and additive manufacturing methods". Journal of Composite Materials, 52(23), 3173-3181, 2018.

[2] Dutra T, Ferreira R, Resende H. "Interlaminar shear strength of continuous carbon fiber reinforced thermoplastic composites manufactured by 3D printing". 24th ABCM International Congress of Mechanical Engineering, Curitiba, Brazil, 3-8 December 2017.

[3] Mohsin MAA, Iannucci L, Greenhalgh ES. "Low-velocity impact performance of carbon fibre reinforced thermoplastic composites for automotive applications". $21^{\text {st }}$ International Conference on Composite Materials, Xi'an, China, 20-25 August 2017.
[4] Chen R, Liu X, Han L, Zhang Z, Li Y. "Morphology, thermal behavior, rheological, and mechanicalproperties of polypropylene/polystyrene blends based onelongation flow". Polymers for Advanced Technologies, 31, 2722-2732, 2020.

[5] Kadlec M, Novakova L, Ruzek R. "An experimental investigation of factors considered for the short beam shear strength evaluation of carbon fiber-reinforced thermoplastic laminates". Journal of Testing and Evaluation, 42B(3), 580-590, 2014.

[6] Zahid S, Nasir MA, Nauman S, Karahan M, Nawab Y, Ali HM, Khalid Y, Nabeel M, Ullah M. "Experimental analysis of ILSS of glass fibre reinforced thermoplastic and thermoset textile composites enhanced with multiwalled carbon nanotubes". Journal of Mechanical Science and Technology, 33(1), 197-204, 2019.

[7] Demir ME, Çelik YH, Kılıçkap E. "Cam ve karbon elyaf takviyeli kompozitlerde elyaf cinsinin, yükün, kayma hızı ve mesafesinin abrasiv aşınmaya etkisi". Journal of Polytechnic, 22(4), 811-817, 2019.

[8] Gauthier MM. Engineered Materials Handbook. Desk ed. First Printing. New York, USA, ASM International, 1995.

[9] Gürdal Z, Raphael T, Hajela P. Design and Optimization of laminated Composite Materials. $1^{\text {st }}$ ed. New York, USA, Wiley Publishing, 1999.

[10] Alcock B, Cabrera NO, Barkoula NM, Peijs AAJM. "Direct forming of all-polypropylene composites products from fabrics made of co-extruded tapes". Applied Composite Materials, 16, 117-134, 2009.

[11] Rajak DK, Pagar DD, Menezes PL, Linul E. "Fiber-reinforced polymer composites: manufacturing, properties, and applications". Polymers, 11(10), 2-37, 2019.

[12] Friedrich K, Hou M. "On stamp forming of curved and flexible geometry components from continuous glass fiber/polypropylene composites". Composites Part A: Applied Science and Manufacturing, 29(3), 217-226, 1998.

[13] Rosselli F, Santare MH. "Comparison of the short beam shear (SBS) and interlaminar shear device (ISD) tests". Composites Part A: Applied Science and Manufacturing, 28(6), 587-594, 1997.

[14] Kim JK, Sham ML. "Impact and delamination failure of woven-fabric composites". Composites Science and Technology, 60, 745-761, 2000.

[15] Dai S, Cunningham PR, Marshall S, Silva C. "Influence of fibre architecture on the tensile, compressive and flexural behaviour of 3D woven composites". Composites Part A: Applied Science and Manufacturing, 69, 195-207, 2015.

[16] Sideridis E, Papadopoulos GA. "Short beam and three point bending tests for the study of shear and flexural properties in unidirectional fiber reinforced epoxy composites". Journal of Applied Polymer Science, 93, 63-74, 2004.

[17] Liu C, Du D, Li H, Hu Y, Xu Y, Tian J, Tao G, Tao J. "Interlaminar failure behavior of GLARE laminates under short-beam three-point-bending load". Composites Part B: Engineering, 97, 361-367, 2016.

[18] Yan W, Han KQ, Qin LL, Yu MH. "Study on long fiber-reinforced thermoplastic composites prepared by in situ solid-state polycondensation". Journal of Applied Polymer Science, 91, 3959-3965, 2004. 
[19] Wang Y, Dong Q, Liu X. "Mode I interlaminar fracture behaviour of continuous glass fibre/polypropylene composites based on commingled yarn". Polymers \& Polymer Composites, 15(3), 229-239, 2007.

[20] Fan Z, Santare MH, Advani SG. "Interlaminar shear strength of glass fiber reinforced epoxy composites enhanced with multi-walled carbon nanotubes". Composites Part A: Applied Science and Manufacturing, 39(3), 540-554, 2008.

[21] Kumar KV, Safiulla M, Ahmed ANK. "An experimental evaluation of fiber reinforced polypropylene thermoplastics for aerospace applications". Journal of Mechanical Engineering, 43(2), 92-97, 2013.

[22] Visweswaraiah SB, Lessard L, Hubert P. "Interlaminar shear behaviour of hybrid fibre architectures of randomly oriented strands combined with laminate groups". Composite Structures, 176, 823-832, 2017.

[23] Huang C, He M, He Y, Xiao J, Zhang J, Ju S, Jiang D. "Exploration relation between interlaminar shear properties of thin-ply laminates under short-beam bending and meso-structures". Journal of Composite Materials, 52(17), 2375-2386, 2017.

[24] Aisyah HA, Paridah MT, Khalina A, Sapuan SM, Wahab MS, Berkalp OB, Lee CH, Lee SH. "Effects of fabric counts and weave designs on the properties of laminated woven kenaf/carbon fibre reinforced epoxy hybrid composites". Polymers, 10(1320), 1-19, 2018.

[25] Bilisik K, Karaduman N, Sapanci E. "Short-beam shear of nanoprepreg/nanostitched three-dimensional carbon/epoxy multiwall carbon nanotube composites". Journal of Composite Materials, 54(3), 311-329, 2020.

[26] Awais H, Nawab Y, Anjang A, Md-Akil H, Abidin MSZ. "Effect of fabric architecture on the shear and impact properties of natural fibre reinforced composites". Composites Part B: Engineering, 2020 https://doi.org/10.1016/j.compositesb.2020.108069.
[27] Yilmaz ND, Khan GMA. Flexural Behavior of TextileReinforced Polymer Composites. Editors: Jawaid M, Thariq NSM. Mechanical and Physical Testing of Biocomposites, Fibre-Reinforced Composites and Hybrid Composites, 13-42, Amsterdam, Netherlands, Woodhead Publishing, 2019.

[28] Adams DF. "Testing tech: the short beam shear test". High Performance Composites, 14(4), 11-12, 2006.

[29] Keith WP, Kedward KT. "Shear damage mechanisms in a woven, nicalon-reinforced ceramic-matrix composite". Journal of the American Ceramic Society, 80(2), 357-364, 2005.

[30] International Organization for Standardization. "Fibre-Reinforced Plastic Composites, Determination of Apparent Interlaminar Shear Strength by Short-Beam Method". Geneva, Switzerland, 14130, 1997.

[31] Zhu J, Imam A, Crane R, Lozano K, Khabashesku VN, Barrera EV. "Processing a glass fiber reinforced vinyl ester composite with nanotube enhancement of interlaminar shear strength". Composites Science and Technology, 67, 1509-1517, 2007.

[32] Seyhan AT, Tanoglu M, Schulte K. "Mode I and mode II fracture toughness of E-glass non-crimp fabric/carbon nanotube (CNT) modified polymer based composites". Engineering Fracture Mechanics, 75, 5151-5162, 2008.

[33] Kumar C, Rawat P, Singh KK, Behera RP, Deep A. "Combined effect of loading rate and percentage by weight of MWCNTs on inter laminar shear strength (ILSS) and flexural strength of CFRP". IOP Conf. Series: Materials Science and Engineering, 2018. https://doi:10.1088/1757-899X/377/1/012074.

[34] Lee J, Park SB, Lee JS, Kim JW. "Improvement in mechanical properties of glass fiber fabric/PVC composites with chopped glass fibers and coupling agent". Materials Research Express, 2017. https://doi.org/10.1088/2053-1591/aa76fa. 